\title{
A New Immigrant Experience of Navigating Multiculturalism and Indigenous Content in Teacher Education
}

\author{
Lilach Marom \\ University of British Columbia
}

\begin{abstract}
In this article, which is grounded in my own experiences, I discuss the responsibilities of new immigrant teacher educators when teaching courses related to diversity and multiculturalism in Canada. I highlight the complexities that underlie discourses of multiculturalism in teacher education, and the important role that new immigrant teacher educators have in locating themselves within the frame of settler colonialism in Canada. I argue that there is a need for genuine dialogue and critical reflexivity that encourage teacher educators and teacher candidates to locate themselves within a complex web of privileges and oppressions, and I explore possible new directions for teaching multiculturalism and Indigenous content in teacher education.
\end{abstract}

\section{Résumé}

Dans cet article fondé sur mon expérience personnelle, je discute des responsabilités des formateurs en enseignement pour nouveaux immigrants lorsqu'ils donnent des cours sur la diversité et le multiculturalisme au Canada. Je mets en lumière la complexité inhérente aux discours sur le multiculturalisme dans la formation des enseignants et le rôle important que tiennent les formateurs en enseignement pour nouveaux immigrants quand ils se positionnent dans le contexte du colonialisme au Canada. Je maintiens qu'il est nécessaire d'établir un dialogue véritable et une réflexivité critique qui encourage les formateurs en enseignement et les étudiants aux programmes de formation en enseignement à se positionner à l'intérieur d'un tissu complexe de privilèges et d'oppressions. J'explore aussi de nouvelles avenues pour enseigner le multiculturalisme et les contenus autochtones dans la formation en enseignement. 


\section{Introduction}

In this article, I share my journey as a new immigrant navigating my way in Canadian multiculturalism as I try to understand and reframe my responsibilities as a teacher educator and a new Canadian citizen. I use what Indigenous scholar Susan Dion (2007) has called critical reflexivity - "critical reflection on self and self in relationship with others situated in a social-political-historical context" (pp. 331-332)-to uncover my location as a White minority (Jewish) immigrant teacher educator teaching multiculturalism in a Canadian university.

I alternate between reflective writing and theoretical framing because, when teaching controversial topics, it is crucial to establish a connection between the personal and the theoretical. This allows us to move from having an abstract "innocent" discussion to arriving at a genuine "dangerous understanding" (Tuck \& Yang, 2012). I start with a methodological note on the genre in which this article is written, followed by the reflective/ theoretical background. I describe an incident in a BEd class that triggered growth in my understanding of the complexities of teaching Indigenous content under the umbrella of multiculturalism in teacher education (Mathur, Dewar, \& DeGagné, 2011; Phung, 2011). I argue that teaching diversity and multiculturalism in teacher education needs to open spaces of genuine dialogue around difference, moving beyond the superficial "decolonization metaphor" (Tuck \& Yang, 2012) to explore the complex past and present relations between settlers, Indigenous peoples, and immigrants in Canada. I conclude with a discussion of the important role that new immigrant teacher educators (and teachers) play in relating to Canada's colonial past and present, and explore possible new directions for teaching multiculturalism and Indigenous content in teacher education.

\section{Methodological Note}

Most academic articles follow a certain writing structure, with separate sections such as introduction, methodological design, literature review, theoretical frame, discussion, and findings. In this article, I break this structure up and weave together my personal voice and the theoretical framework. Preissle (2007) argued "against privileging the abstract over the concrete, the principle over the relationship, the absolute over the relative, the universal over the particular, the objective over the subjective, and the cognitive over the affective" (p. 518). I find this argument appropriate for this article, which emerged from my experiences as a new immigrant teacher educator teaching controversial issues in a pre-service teacher education program. These experiences expanded my knowledge of multiculturalism as a theoretical frame for the complexity of Canada's past and present. Since this was an organic process involving emotions, reflections, and theorizing, cutting it into stand-alone units risked alienating the writing and creating an artificial distance that would not serve the purpose of this article, in which I "[embrace] not detachment but engagement as the road to knowledge" (Burawoy, 1998, p. 5). This article is thus written as a form of autoethnography (Denzin, 2014), highlighting "the relationship between the personal, the political, and the historical" (Wyatt, Gale, Gannon, Davies, Denzin, \& St. Pierre, 2014, p. 413). 


\section{Background}

When I arrived in Canada as a new immigrant in 2011, I thought of it as a haven, a multicultural society where I could raise my children peacefully, and the complete opposite of the contested land of Israel, my homeland. When I arrived at the airport's immigration desk, the first official document I was handed reinforced my expectations: the permanent residency guidelines declared that: “Canada's population of around 31 million people reflects a cultural, ethnic, and linguistic mix that is unique in the world. Canadian multiculturalism is based on the belief that all citizens are equal and that diversity makes us stronger as a country" (Government of Canada, 2014, para. 2). Coming from a state that privileges its Jewish citizens over others, ${ }^{1}$ I read this description as a promise of a multicultural and inclusive society.

Canada is considered the first country to embrace multiculturalism as an official policy (Johnson \& Joshee, 2007; Wright, Singh, \& Race, 2012). Canadian multiculturalism is conceptualized according to Canada's three founding populations-the French, the English, and the First Nations-but is also open to recognizing other cultures as an integral part of Canadian society (Wright et al., 2012). Former Prime Minister Pierre Trudeau, the architect of Canadian multiculturalism, claimed that no official culture or ethnic group came before any other (Graham, 1998). However, the unique construction of Canadian multiculturalism is not an outcome of Western inheritance, but of First Nations values (Saul, 2009). As a policy, multiculturalism within a bilingual framework was officially announced at the beginning of the 1970 s and famously codified into the Multiculturalism Act of 1988. It is first and foremost a demographic imperative, a tool to create social cohesion, and an answer to pressures of minority groups within (e.g., Québécois, Ukrainian) and powers from outside (e.g., American influence) (Fleras \& Elliott, 2002). It has also emerged from economic motives, namely, attracting immigrants to increase competitiveness and profitability in the global market (Deters, 2011).

Prior to arriving in Canada in 2011, I did not know much about its history, aside from the overarching story of the discovery/colonization of the land by (mostly) European settlers. Therefore, in the graduate students' orientation session of my department at the University of British Columbia (UBC), I was quite surprised by the Graduate Advisor's acknowledgement that "UBC's Point Grey Campus is located on the traditional and ancestral territory of the $\mathrm{x}^{\mathrm{w}} \mathrm{m} \partial \theta \mathrm{k}^{\mathrm{w}}$ əyəm (Musqueam) people" (for a written declaration, see UBC, 2015). He then continued, without explanation, by addressing the other agenda items. Meanwhile, I was confused; I had not expected this, and I felt certain that other students who were new immigrants or international students were feeling the same. As $\mathrm{Yu}$ (2011) explained:

[M]any new arrivals in Canada received very little information about the history of Aboriginal people and, in particular, of the devastating effects of governmental policies such as residential schooling; therefore, through no intention of their own, they [new immigrants] were often left only with stereotypes and the negative images of popular culture as the basis for their knowledge about Aboriginal people. (p. 301)

In my home country of Israel, two groups fight over recognition as indigenous to the land, their justifications dating all the way back to the time of the Bible and the Koran. 
A public figure in Israel acknowledging at an institutional event that Tel-Aviv University was located on the unceded territory of Sheikh Munis ${ }^{2}$ is unimaginable. I was genuinely impressed with this progressive declaration. In Israel, the land is a source of bloody, militaristic, ongoing conflict, and many fear that public acknowledgement may lead to ceding parts of the current state of Israel and allowing the return of thousands of Palestinian refugees. Not surprisingly, I was, therefore, grappling with the meaning of such an acknowledgement in the Canadian context. What is the relationship between the acknowledgement of land rights and the reclaiming of that land? Who has title to the land?

\section{Integrating Indigenous Content into Teacher Education}

During my PhD program, I tried to become more familiar with the Canadian history of Indigenous peoples. I began to understand the complexity of this history and its continued effects on Indigenous peoples, and gained some understanding of Indigenous knowledges, frameworks (such as the different concept of the ownership of the land), and pedagogies (Donald, 2012; Haig-Brown, 2011; Sanford, Williams, Hopper, \& McGregor, 2012). Still, in my first years in Canada, I understood multiculturalism as a generic frame for dealing with diversity. Furthermore, I was mostly aware that many immigrants in Vancouver "did not fit" the "White image" I had of Canada (BC Stats, 2013). In BC, most immigrants (70\%) are of Asian origin, and 80\% are "visible minorities" (BC Stats, 2013). Seeing myself as someone who had emigrated from one Western country to another (an arguable claim when thinking of Israel), I held some stereotypes regarding the dichotomy between Asian cultures and Western cultures (Collins \& Reid, 2012). As a Western White immigrant, I wondered what the role of multiculturalism was in bridging East-West differences, and what multiculturalism would look like when Whites were no longer the majority in the Greater Vancouver area. As Yu (2011) argued:

Vancouver . . . has become a city in which the term "visible minority" makes no sense. In 2006, four out of 10 Vancouverites had been born outside of Canada, and five out of 10 were of Asian ancestry. . . . In Vancouver . . . the "visible minority" is "white." (p. 306)

However, even when racial and ethnic minority groups become the numerical majority, they are still socially constructed as marginalized (Chase, Dowd, Pazich, \& Bensimon, 2012; Dowd, 2008). Hence, I began to understand the complexity of multiculturalism and the tensions beneath the "celebration of cultures" (Gorski, 2009; Orlowski, 2008). In my case, I feared becoming a White minority, although I chose to overlook the many differences between me and White-Anglo Canadians, such as my being Jewish and of an audible minority, and focused instead on the similarities. Because I was preoccupied with locating myself as an immigrant in the social space of White Canadians and more prevalent immigrant groups, I did not consider my location as a new settler on Indigenous land and how, by becoming part of Canadian society, I was joining an ongoing "settler colonialism" (Tuck \& Yang, 2012).

I remember attending a workshop given by a renowned Indigenous scholar, at which the participants introduced themselves in a circle: all the Indigenous participants introduced themselves as Indigenous from a specific location, followed by their Native name, while the non-Indigenous participants identified themselves as second- or third-generation settlers, 
along with their (usually European) country of origin (there were also some participants of mixed ancestry). I struggled to collect my thoughts on the appropriate thing to say, and when it was my turn, I said: "I'm Lilach, and I am from Israel." It was the first time that I understood that using the term "new immigrant" also carried a political meaning.

I began to work with the concept of critical multiculturalism as a way to challenge and revitalize the concept of multiculturalism and the essentialist definitions that are assigned to (some) cultures. Critics claim that Canadian multiculturalism is rooted in a liberal frame, is "colour-blind," and focuses more on the "celebration of cultures" than on past struggles and power inequities (Orlowski, 2008). A related claim is that Canadian multiculturalism has not really dealt with racism and colonialism (St. Denis, 2011). Simpson, James, and Mack (2011) have argued that "Canada is a White settler colony built on the expropriation of Indigenous land, erasure of Indigenous histories, and ongoing colonization" (p. 285). From this perspective, Canadian history should be framed by its colonial context, in which racism and colonialism interplay in a complicated manner (for instance, people of colour do not necessarily identify with Indigenous claims) (Thobani, 2007). Simpson, James, and Mack (2011) claimed that in Canada, discourses of racism and colonialism are located under the multicultural umbrella in order to reduce their importance and avoid discussing them fully; hence, Canada, the country that symbolizes multiculturalism in both policy and practice, is actually using it as a mechanism to ignore the systemic operation of racism and colonialism at the structural and institutional levels.

Critical multiculturalism is a radical version of multiculturalism. It was developed in the 1990 s as a way to challenge the decline of multiculturalism on both the theoretical and the practical levels (May, 1999). Critical multiculturalism focuses "on the multiple ways in which we inhabit hegemonic narratives of culture, race, ethnicity, socioeconomic class, gender, language, sexual orientation, and ability, and how these narratives inhabit us" (Lea, 2010, p. 37). Critical multiculturalism challenges power relations and inequalities embedded in Western societies. According to critical multiculturalism, disparities are often ethnically based; hence, it highlights the "wider manifestations of racism that extend beyond color, at least in the ways they are expressed" (May \& Sleeter, 2010, p. 8). Aboriginal people and most immigrants in $\mathrm{BC}$ are from minoritized groups, but in North America, Aboriginal people are also generally portrayed as deficient, while some immigrant groups (especially East Asians) are portrayed as "model minorities," albeit still deficient in certain ways (Alvarez, Juang, \& Liang, 2006; Nguyen, 2011). Sharing Lawrence and Dua's (2011) claim that "writers fail to make Indigenous presence and ongoing colonization, particularly in the Americas, foundational to their analyses of race and racism" (pp. 243-244), I am aware that belonging to a racialized group does not equate to or erase all other social locations (Phung, 2011).

While both Indigenous peoples and immigrants might be affected by overlapping but distinct mechanisms of oppression embedded in the Canadian state, they are positioned in relation to each other in contested ways. It seems there is a theoretical divide in studying these two groups (Lawrence \& Dua, 2011; Yu, 2011), partly due to the critique by Indigenous scholars of "[erasing] the specific and unique location of Aboriginal peoples as Indigenous to this land by equating them with multicultural and immigrant groups" (St. Denis, 2011, p. 311). Most scholars cited here argue that the multicultural frame is too polluted by colonialism and racism to be redeemed; however, as Lawrence and Dua (2011) 
have argued, "there is a need for scholarship that ends practices of segregation, and attempts to explore the complex histories of interactions between peoples of colour and $\mathrm{Ab}-$ original peoples" (p. 254). I suggest that decolonizing is possible within multiculturalism if it is to be understood as a critical theory. Critical multiculturalism could build on the familiarity of multicultural terminology in Canadian society, while offering crucial revisions rather than a complete dismissal. There is an urgent need to weave the particularity of Indigenous history and Indigenous peoples' prominent place as the founding peoples of Canada into the current Canadian context in which Indigenous and immigrant groups are the two fastest growing populations (Statistics Canada, 2015). As Yu (2011) argued:

To those Aboriginal people whose ancestors welcomed the first trans-Atlantic and trans-Pacific migrants to these shores, everyone else is a migrant to their homeland. If we are to all make a home together here, there can be no reconciliation with the inequities of our past until this simple truth is recognized. But the demographic reality of our present and future must also be taken into account. (p. 305)

Indeed, Indigenous scholars reject the seamless bridging of the past and the present, especially within a reality in which treaty promises remain broken, fundamental traditional rights of Indigenous lands remain stuck at the declarative level, and Indigenous children remain systematically discriminated against in schools (Foster, Raven, \& Webber, 2011; First Nations and Indigenous Studies Program, UBC, 2014). Furthermore, there is a need for systemic curricular change to present the White-European perspective for what it really is, one perspective out of many, and alternatively, start from the standpoint of Indigenous peoples. And yet, if we, as educators, aim to create bonds across differences, enhance understandings, and form an inclusive educational space, critical multiculturalism could serve as a meaningful platform.

Through the critical multiculturalism frame, I unfolded my essentialist assumptions about certain cultures and explored the hidden colour of Whiteness (McIntosh, 2003). However, without being fully aware of it, I reduced my engagement with Indigenous content. This was reflected in my teaching as a sessional instructor. In my first year, although I knew little about Canadian society, I felt that Indigenous content (one of the topics suggested in the master syllabus) was central to a course on social justice and education. Hence, it seemed reasonable to include two readings on Indigenous issues within a course that touched briefly on a wide range of topics. In hindsight, I recognize that I replaced these articles with others that raised similar questions but in different contexts (e.g., oppression of African-Americans in the United States).

Reflecting on these choices, I believe that I sensed that Indigenous content was sensitive and controversial and that there was a social division: some (Indigenous scholars, scholars who work on Indigenous areas, or social activists) were very knowledgeable, while others knew little to nothing. As Godlewska, Moore, and Bednasek (2010) pointed out: "Ignorance has been used to structure Canada's relations with Aboriginal Peoples for hundreds of years" (p. 436).

Even in UBC's Faculty of Education, a leader in Indigenous education, with a Native Indian Teacher Education Program, most instructors and teacher candidates have limited knowledge of Indigenous issues. In a survey of the 2012 graduating cohort, only $38 \%$ said they "feel comfortable about my ability to address the needs of Aboriginal learners" (UBC, 
2013, p. 16). This was one reason its teacher education program was redesigned (Teacher Education Office, 2016) to include an emphasis on "diversity, and social and ecological justice," a "mandatory course on Aboriginal education," and an "infusion of Aboriginal perspectives throughout the program" (Teacher Education Office, 2016, p. 1). In addition, in 2012-2013, the UBC Faculty of Education observed "The Year of Indigenous Education" and introduced many resources to help teachers teach Indigenous content.

Despite these efforts, Indigenous content remains a very charged topic that many resist (Strong-Wilson, 2007). Colleagues who taught the newly introduced "Aboriginal Education in Canada" course said they often experienced strong resistance from teacher candidates. In my case, I was unconsciously feeling that unless I was a "real" expert, it would be safer to avoid this topic in my teaching. I told myself that I would not need to cover Indigenous issues because Indigenous topics would be covered elsewhere by "expert instructors."

Many Canadians are not informed about or engaged with Indigenous knowledges, perspectives, and political struggles; the same is true of many teachers and teacher educators. In their study of elementary- and secondary-school teachers in Canadian schools, Higgins, Madden, and Korteweg (2015) demonstrated that the "overwhelming majority of white teachers were occupying and upholding the position of the perfect stranger" (p. 254). What I emphasize is the complexity of engaging with these topics as a new immigrant teacher educator. In a way, I was initiated into "Canadianism" by choosing to participate in the Canadian collective ignorance rather than negotiating my own place and responsibilities as a newcomer to Canadian society. This perspective needs to be examined, since a growing number of immigrants and second-generation immigrant teachers are entering the Canadian K-12 system (Schmidt, 2010; Walsh, Brigham, \& Wang, 2011). As with other immigrants, such teachers, especially those from non-Western countries, try to "fit into" the receiving society (Egbo, 2011), while often being exposed to oppression based on race, ethnicity, and immigration status (Singh, 2005). Furthermore, teachers and teacher educators who come from countries where land rights and Indigeneity have multiple constructions that are not necessarily consistent with the Canadian context need to negotiate their social location as new settlers (a location that is often ignored by White settler Canadians) during the complex process of immigration.

The immigration experience can also move one beyond prevalent Canadian educational discourses, as immigration destabilizes one's social location and unveils cultural constructions that may have been invisible to the immigrant before. Perhaps the experience, which puts one in a hybrid position between countries and cultures, triggers reflective awareness. As Williams (2007) suggested, "migrants may have a particular capacity for reflexivity" (p. 367). In my case, before immigrating to Canada, I was never fully aware of my White privilege; only once I lost some of that privilege did I become aware of it (McIntosh, 2003). I demonstrate this complexity by describing an incident in a class I was teaching for UBC's teacher education program.

\section{How Does One Deal with Mistakes?}

This incident occurred in a foundation course on the overlapping connections of school, society, and education. The syllabus for the course states: "This course aims to illustrate how schooling is a site for competing politics and philosophies about the role of education in society and the work of teachers." The course proceeds as a series of "big" 
socio-political topics for teacher candidates to engage with in the first term of their program. In the class on diversity and multiculturalism, I asked the students what came to mind when they heard the word multiculturalism. The key words were: diversity, mosaic, and celebration of cultures. Hence, most responses reinforced an understanding of multiculturalism as a positive frame that allows for diversity and inclusion. I wanted to challenge this ideal picture of the multicultural mosaic (Dei, 2000; Porter, 1965) to point out the power dynamics embedded in a seemingly "neutral" framework. But I also wanted to acknowledge that multiculturalism is still an important frame, especially in the face of national backlashes against multiculturalism in many Western countries, particularly in the European Union (Wright et al., 2012).

From my experience teaching this course over the last three years, I knew that teacher candidates understood this course as one that dealt with contested issues. And because I believed that teaching controversial topics was much more effective when connected to one's own location and set of lived experiences, I gave the students the task to share within their discussion groups their personal experiences of multiculturalism and diversity in Canada. It is important to note that although many argue that teaching is a White, middle-class profession (see Sleeter \& Milner, 2011), in my three years of teaching at UBC, I saw a growing diversity of new teacher candidates within the student body. In my classes, I observed a student body of approximately 25-30\% immigrants or second-generation immigrants, most of them from "visible minority" groups (mostly East Asian and South Asian).

After students expressed their opinions in their small groups, I shared my own reflections, since part of my teaching philosophy is to connect my teachings to my own social location. I wanted to highlight the achievements and the shortcomings of the multicultural frame, so I said that as a new immigrant, and as someone from a Jewish state, I was genuinely impressed when I first heard the acknowledgement by UBC administrators that the university was located on Indigenous land. I emphasized that in Israel, this would not happen because there are two groups actively fighting over recognition as indigenous to the land of Israel. I added that in Canada, this acknowledgement is much easier, since in Israel there is an ongoing war, and in Canada, the war has already been won, and it is clear who the losers were.

As I was speaking, I immediately sensed my words were not being interpreted as I intended. As a non-native English speaker, I was translating my thoughts from Hebrew, in which the word "loser" does not imply deficit or victimization; rather, its meaning is confined to a military context. What I meant was that in Canada, there is an ongoing history of land being brutally stolen or taken away from Indigenous peoples, whereas Israel is still in a constant state of war. However, I felt that my words might have been completely misinterpreted given the significant differences in historical context. But since I was engaging in this act of reflecting while teaching, I simply moved on, even while trying to review in my head what I had said to the students to understand how they might have heard it. ${ }^{3}$

I was worried that I had said something that might be interpreted as reinforcing assumptions of deficiencies about Indigenous peoples, assumptions that I knew some teacher candidates might have. But I was unsure how to remedy this miscommunication and misunderstanding. I was taking "the position of perfect stranger" (Dion, 2007, p. 331) that many teachers display when teaching Indigenous content, as "they know that ways of teaching that reproduce stereotypical representations are inadequate, thus there is a fear and a silence involved in addressing this content" (p. 331). 
When the class was over, I became concerned that I had used the space of the class and my authoritative position as a teacher educator in a way that might "reproduce stereotypical representations." As Orlowsky (2008) has argued, "it is clear that teachers are in the role of hegemonic agents, or possibly counter-hegemonic agents, whether they are conscious of this or not" (p. 2). I was clearly in the first category. I understood that I had unintentionally repeated two prevalent Canadian assumptions about Indigenous peoples: that they are deficient, and that there had been a war over the land in Canada. By using a comparison from another context and the terminology of war, I had overlooked Canada's colonial history. As St. Denis (2011) argued, "When colonialism in Canada is left unaddressed, racialized ethnic immigrants are too easily positioned as innocent" (p. 311). In this case, I took not only the position of a hegemonic agent (as a teacher), but also that of an "innocent" new immigrant and ethnic minority.

While the above section theorizes this classroom incident, I was not primarily occupied with theoretical framing. Rather, I was distressed and feeling my foreignness more than ever. I felt this incident was an outcome of a poor literal translation and a failed attempt to summarize a complex and different context of Indigeneity. But the damage had been done, and I needed to consider how to address it. I wrote an apologetic email to the students in the class, adding that I would apologize to them face-to-face in the next class and would open a discussion on the incident. I was hoping to liberate the space of the class that I occupied with my words and position of authority. I also hoped that my students might learn something from this mistake, and that I would be able to demonstrate what to do if something of this sort happened to them: that is, do not ignore embarrassing teaching moments-own up to your mistakes.

I also considered the right way to open the class to this discussion. As mentioned above, I assumed most of the students were White Canadians or of Asian heritage but did not want to impose self-identifications on them. ${ }^{4}$ Although I try in my teaching to move beyond essentialist cultural identifications, I needed to take my own location (or perceived location) into account. I thought that my social location as a White Israeli immigrant should be considered, given that I was from a country that could represent the most concrete example of contemporary colonialism. I was worried that some in my class might feel unsafe and offended by my words and wanted to make sure the class space remained safe for all my students.

I approached my colleague, Dr. Amy Parent, an Indigenous scholar, and asked for help in navigating the situation. In hindsight, I am aware that inviting an Indigenous scholar to join the class may have been perceived as reproducing the same kind of distant and disengaged position that many White teachers take (Higgins et al., 2015), and that this might have allowed me to be "safe" rather than confront the real need to interrupt and disrupt the colonial discourse (Tupper, 2013). However, I felt painfully foreign and out of place and needed a colleague to guide me. ${ }^{5}$ We decided to lead a class together in the First Nations House of Learning, where we would discuss how to teach Indigenous topics and reflect on some of the problems that are hidden under the multicultural discourse. We designed a class in which the students would work with quotes that would open up some of the misconceptions about Indigenous peoples' deficits, as well as Indigenous critiques of the erasure of the ongoing realities of neocolonialism under the multicultural discourse of education. 
It is important to note that I am aware that one class is hardly sufficient to deal with the complexity of the topic, and that a deep institutional change is needed to truly include $\mathrm{Ab}$ original education at the core of teacher education. UBC is making many efforts in this direction (Teaching for Indigenous Education, 2015), but there is a lot more work to be done. ${ }^{6}$

In the subsequent class, I apologized to the students and shared my thoughts and emotional processing of the issue, including my guilt and paralysis and how I planned to repair the situation by co-facilitating a class discussion in partnership with an Indigenous educator as a way to create a safer space for a genuine discussion. Many students thanked me and said that they had learned a lot from my apology and public reflection. A few students told me I should not feel bad, and that it was very clear that I did not mean to say anything diminishing. I was relieved, but also worried by these second reactions, since I was not sure if I was actually understood, or if those students just thought that it was not a "big deal," or perhaps viewed it as simply my personal mistake, rather than a symbol of a much larger issue.

Amy and I co-taught the class, rather than position her as the "expert to the rescue." As mentioned, we held the class at UBC's First Nations House of Learning and began by introducing the house poles (I was surprised that very few of the students knew that the House of Learning existed). We then reviewed the " $4 \mathrm{Rs}$ " for creating an environment of learning Indigenous content-respect, relevance, reciprocity, and responsibility (Kirkness \& Barnhardt, 1991) - and discussed basic terminology. Midway through the class, the students rotated in small groups between the different quotes. I sat near the following quote:

Aboriginal people adamantly reject this equating of their Aboriginal position with ethnic minorities as a form of colonialism (Curthoys, 2000; Short, 2005). Whether through anti-racism or multiculturalism, when colonialism in Canada is left unaddressed, racialized ethnic immigrants are too easily positioned as innocent. (St. Denis, 2011, p. 311)

Under this quote we wrote, "What is a settler?" I sat near this poster because I wanted to encourage them to ask whether White Canadians, minoritized Canadians, and new immigrants are all settlers in a similar way (Phung, 2011). I was surprised that many thought that settlers were people who "leave their home country and move to a different country." Hence, if you are born in a country then you are not deemed a settler. These students expressed what Mawhinney (1998) called "settler moves for innocence": settlers take on the innocent position that allows them to overlook the distinct form of "settler colonialism" (cited in Tuck \& Yang, 2012, p. 9).

My students demonstrated another "move for innocence" in which most White Canadian students do not see themselves as settlers, while immigrants are then positioned as the actual settlers. In this activity, the majority of my teacher candidates attributed the term "settler" and the positionality of settlers only to first-generation racialized immigrants. As Yu (2011) argued:

One of the triumphs of a white supremacist colonial history of Canada was the mythical alchemy that made it possible for everyone who arrived from Europe to become a "Canadian," and for all those who were non-white to remain a "visible minority," forever arriving late, or a "native" forever destined to disappear. (pp. 304-305) 
In concluding this quote-response activity, students shared their thoughts with the larger group. The discussion centred on the Indigenous critique of multiculturalism in Canada. The air was tense, and I could sense hesitation and fear of speaking. Only a few people talked, and the rest seemed worried about saying something wrong. As Dion (2007) argued: "The classroom and school context encompass fear of confrontation, of saying the wrong things, of exposing ignorance, of contradicting parents, faith communities, and the official curriculum" (p. 334). At the same time, as Tupper (2013) explained: "The creation of discomfort/disruption in teacher education spaces should be viewed as not only an essential condition for (white) preservice teachers, but also for teacher educators" (pp. 49-50).

After the class, I became aware of the deep currents of misinformation, misrepresentation, stereotypes, and chronic ignorance circulating and reproducing under the evasive theoretical discussions on social justice and multiculturalism. I began to understand the serious burden carried by the few who teach the mandatory Indigenous course that was recently added to the curriculum, and who had to untangle the theoretical and emotional complexities of this discussion. Furthermore, I began to better understand the fear of many Indigenous peoples that the massive immigration to Canada would further dilute the unique and distinct status of Indigenous peoples as the First Nations and First Peoples of Canada, and that it would create a new set of misinterpretations, such as identifying new immigrants as the real settlers, or exempt new immigrants from the responsibility related to Canada's wrongdoings in the past and present. ${ }^{7}$ Can teacher education find a way to transcend this ongoing neocolonialism?

\section{Concluding Thoughts}

As a teacher educator, I felt I had made an effort to acknowledge and correct my own settler-colonial mistake: I apologized publicly, reflected on my position in front of the class, and tried to open a space for discussion. Many students said they appreciated my reaction and reparative response, and that they had learned what to do if something similar happened to them.

This incident made me realize that there are deeper systemic currents of racism and neocolonialism that circulate continuously in the BEd curriculum but that are particularly exposed when teaching Indigenous content. It triggered a reflective journey that was initiated during a UBC graduate student orientation, when I first became aware of Canadian Indigenous history; I then began to engage in thinking about this reality of Canada but nonetheless decided to leave others to deal with it. By doing so, as a new immigrant teacher educator I was contributing to the theoretical, educational, and practical exemption of understanding immigration within the frame of neocolonialism. This event triggered further critical reflection, which changed the way I think about myself as a Canadian citizen and teacher educator. I now understand that one class and one public apology are at best superficial and may even be harmful. If I really want to move beyond decolonizing as a metaphor (Tuck \& Yang, 2012), I have to take an active role in resisting Canada's ongoing colonialism and change my teaching to reflect this commitment.

This incident furthered my understanding of my responsibilities as a new immigrant and settler teacher educator in Canada. It also furthered my new understanding that by not taking a stand on Indigenous education, I am, in effect, reinforcing settler-colonialism. 
I realized that by including Indigenous topics under the title of diversity and multiculturalism, and only briefly acknowledging the differences, I was contributing to a superficial understanding of multiculturalism and an ignorance of Indigenous peoples and issues. Through this incident I understood that as a new immigrant, I can either enhance the engagement of teacher candidates with Indigenous content or contribute to the silencing and superficial discourse and the reproduction of settler-colonialism that disadvantages Indigenous children and people in our schools.

I, as a new immigrant teacher educator, can expose and unpack with pre-service teachers the intersections and the unique distinctions of each social group in order to begin conversations that will engage all Canadian educators in reconsidering the Indigenous-nonIndigenous relationships that are at the core of Canadian society (Donald, 2012). As a new immigrant, I am in a different position than Canadian-born citizens (regardless of their ethnicity or cultural heritage), since I chose to become a Canadian citizen. As such, I have a lead responsibility to locate myself within the frame of Canadian settler-colonialism as a role model for both racialized and White settlers on how all Canadian educators need to confront these issues (Phung, 2011). In my case, I am a descendent of the Jewish indigenous people of Israel, who for many years were away from, but never forgot about, their homeland (Clifford, 1997). When finally returning to this land, they then deprived the indigenous Palestinians of their land rights. This ongoing injustice drove me out of my country, but what ethical responsibilities have I now assumed when making Canada my new home?

I can model for my students an important responsibility: that even though I was not aware of Canada's injustices, past and present, before arriving here, and even though as a new immigrant, I myself am positioned in a deficient social location by mainstream Canadian society, I am still a colonial settler on unceded Indigenous land. As a new immigrant, I am also aware of the discrimination that many immigrants experience based on their colour, ethnicity, lack of English proficiency or lack of familiarity and social networks in Canada. Oppression works in multiple directions: new immigrants and people of colour can be oppressors while also being oppressed. ${ }^{8}$

What is missing and what is needed most is genuine dialogue and critical reflexivity that will encourage teacher educators and teacher candidates to locate themselves within a complex web of privileges and oppressions (Crenshaw, 1991). This is what Donald (2012) called "ethical relationality" - "an ecological understanding of human relationality that does not deny difference, but rather seeks to understand more deeply how our different histories and experiences position us in relation to each other" (p. 531).

As demonstrated in this article, many scholars argue that such "ethical relationality" cannot be developed under the ill-defined frame of multicultural education. I agree that a multiculturalism that does not acknowledge White-Western supremacy, and that reproduces an ongoing colonialism, cannot serve as an umbrella for ethical relationships and cannot be the frame through which we educate Canada's future teachers. New immigrant teacher educators have a role in exploring, along with teacher candidates, the tensions with and misrepresentations of Indigenous issues that are embedded in multicultural discourses of teaching and education. If this does not happen, White supremacy will be reproduced or become more deeply entrenched. Settler colonialism has not only oppressed Indigenous peoples and their relationship to their land, but also created superficial categories of Indigeneity, immigration, and Whiteness that overlook the diversity of each of 
these groups. Thus, I believe that grounding education in the multiple is a more effective way to foster understanding of commonality and difference.

In the classes I currently teach, I begin with my location. I open my courses by acknowledging the Indigenous peoples on whose unceded land the course takes place, and I share my questions regarding my commitments to past and present colonialism as a new Canadian citizen. I invite all students, with their diverse experiences and social backgrounds, to locate themselves in relation to settler colonialism and prompt them to identify other forms of oppression without comparing or diffusing them, but rather by identifying the singularities and the intersections. Such discussions should not be grounded in guilt but in reflexivity. We are all born to a certain location but can also shift locations, take on commitments, and establish relationality. This kind of teaching could open an educational space in which immigrant teachers, settler teachers, and Indigenous teachers align, instead of positioning themselves against each other, and in which they resist settler colonialism and its intersections with other forms of oppression.

Such dialogue could lead to a new understanding of multiculturalism as a critical theory that acknowledges the unique location of Indigenous people, the ongoing colonial legacy of Canada, and the challenges that immigrants face. Such a concept of critical multiculturalism starts with Indigenous peoples, while inviting other groups and cultures to weave their experiences into a human quilt that resists settler colonialism and other forms of oppression by exploring the singularity and relationality of people and land. This process is crucial for the future construction of Canada as a truly multicultural space rooted in the past and open to the future.

\section{Notes}

1 Israel is a unique case of a Jewish democratic state. Although not all of its citizens are Jewish, Jews have privileged position de jure and de facto.

$2 \quad$ A Palestinian village that existed in this area until the war of 1948.

3 There is a video produced by the First Nations and Indigenous Studies Program at UBC in which Indigenous students share what they have heard in their classes (First Nation Studies Program, UBC, 2014).

4 One problem with artificial multiculturalism is that it identifies cultures superficially, according to visibility and traditions. I experienced this many times when asked to be the "representative Jew" in my children's schools and to teach their classmates about Jewish customs. I continue to play this role, although my self-identification as Jewish is very far from the conservative image I am asked to portray.

5 My colleague played an essential role in this process in assuring me that I am not alone, that it is okay to make mistakes, and that this is part of my learning process. This collaboration was very important in furthering my own learning process; moreover, I think that whenever such collaborations are possible (e.g., co-teaching) they can provide a rounded learning environment for students.

6 For example, as a new instructor, I was never introduced to the complexity of multiculturalism and colonialism, and in my first year of teaching at UBC, I discussed multiculturalism without fully realizing how contested this term is in the Canadian context.

7 Recently, I became a Canadian citizen. As part of this process I had to take a "citizenship test," for which I prepared using the official study guide, Discover Canada: 
The Rights and Responsibilities of Citizenship (Citizenship and Immigration Canada, 2012). In this guide, under the title, "Who We Are," Aboriginal Peoples are presented as one of Canada's "three founding peoples," along with the French and British (p. 10). After a short paragraph about residential schools, the guide declares: "In 2008, Ottawa formally apologized to the former students" (p. 10). It is very clear that the official narrative that initiates immigrants into "Canadianism" not only ignores ongoing colonialism, but also reproduces ignorance and innocence.

8 My Israeli background has taught me that quantifying oppression leads only to otherness and destruction. Having been displaced from their land, and having been a target of constant persecution, might have contributed to the fact that when the Jewish people finally seized power, they turned a blind eye to the indigenous Palestinians' land rights.

\section{Acknowledgements}

I would like to give my thanks to Amy Parent, Dwayne Donald, Michael Marker, Maren Elfert, and Mark Turin for their constructive feedback and their support, and to the CJHE editor, Michelle Pidgeon, and the anonymous reviewers for their enlightening comments and suggestions.

\section{References}

Alvarez, A. N., Juang, L., \& Liang, C. T. (2006). Asian Americans and racism: When bad things happen to "model minorities." Cultural Diversity and Ethnic Minority Psychology, 12(3), 477-492.

BC Stats. (2013). Quarterly population highlights. Retrieved from http://www. bcstats.gov.bc.ca/StatisticsBySubject/Demography.aspx

Burawoy, M. (1998). The extended case method. Sociological Theory, 16(1), 4-33. doi:10.1111/0735-2751.00040

Canadian Multiculturalism Act, Revised Statutes of Canada. (1988, c. 31). Retrieved from the Government of Canada's Justice Laws website at http://laws-lois.justice.gc.ca/ eng/acts/c-18.7/page-1.html

Chase, M. M., Dowd, A. C., Pazich, L. B., \& Bensimon, E. M. (2012). Transfer equity for "minoritized" students: A critical policy analysis of seven states. Educational Policy, 1-49. Available at http://epx.sagepub.com/content/early/2012/12/o6/0895904812468227

Churchill, W. (1947). Winston S. Churchill: His complete speeches, 1897-1963. Retrieved from http://www.bartleby.com/73/417.html

Citizenship and Immigration Canada. (2012). Discover Canada: The rights and responsibilities of citizenship. Retrieved from http://www.cic.gc.ca/english/resources/ publications/discover/

Clifford, J. R. (1997). Travel and translation in the late twentieth century. Cambridge, MA: Harvard University Press.

Collins, J., \& Reid, C. (2012). Immigrant teachers in Australia. Cosmopolitan Civil Societies Journal, 4(2), 38-61. 
Crenshaw, K. (1991). Mapping the margins: Intersectionality, identity politics, and violence against women of color. Stanford Law Review, 43(6), 1241-1299.

Dei, G. (2000). Contesting the future: Anti-racism and Canadian diversity. In S. E. Nancoo (Ed.), 21st century Canadian diversity (pp. 295-319). Mississauga, ON: Canadian Educators' Press.

Denzin, N. (2014). Interpretive autoethnography. Thousand Oaks, CA: SAGE Publications.

Deters, P. (2011). Identity, agency, and the acquisition of professional language and culture. New York, NY: Continuum.

Dion, S. (2007). Disrupting molded images: Identities, responsibilities and relationships-teachers and indigenous subject material. Teaching Education, 18(4), 329-342. doi:10.1080/10476210701687625

Donald, D. (2012). Indigenous métissage: A decolonizing research sensibility. International Journal of Qualitative Studies in Education, 25(5), 533-523. doi:10.1080 /09518398.2011.554449

Dowd, A. C. (2008). The community college as gateway and gatekeeper: Moving beyond the access "saga" to outcome equity. Harvard Educational Review, 77, 407-419.

Egbo, B. (2011). What should pre-service teachers know about race and diversity? Exploring a critical knowledge-base for teaching in 21st century Canadian classrooms. Journal of Contemporary Issues in Education, 6, 23-37.

First Nations and Indigenous Studies Program, UBC. (2014). What I learned in class today: Aboriginal issues in the classroom. Retrieved from http://www. whatilearnedinclasstoday.com/

Fleras, A., \& Elliott, J. H. L. (2002). Engaging diversity: Multiculturalism in Canada. Toronto, ON: Nelson Thomson Learning.

Foster, H., Raven, H., \& Webber, J. (Eds.). (2011). Let right be done: Aboriginal title, the Calder case, and the future of Indigenous rights. Vancouver, BC: UBC Press.

Godlewska, A., Moore, J., \& Bednasek, C. D. (2010). Cultivating ignorance of Aboriginal realities. The Canadian Geographer, 54(4), 417-440.

Gorski, P. C. (2009). What we're teaching teachers: An analysis of multicultural teacher education coursework syllabi. Teaching and Teacher Education, 25(2), 309-318. doi:10.1016/j.tate.2008.07.008

Government of Canada. (2014). Adjusting to life in Canada. Retrieved from http:// www.cic.gc.ca/english/newcomers/after-life.asp

Graham, R. (Ed.). (1998). The essential Trudeau. Toronto, ON: McClelland \& Stewart.

Haig-Brown, C. (2011). Decolonizing diaspora. In A. Abdi (Ed.), Decolonizing philosophies of education (pp. 73-90). Rotterdam, The Netherlands: Sense Publishers.

Higgins, M., Madden, B., \& Korteweg, L. (2015). Witnessing (halted) deconstruction: White teachers' "perfect stranger" position within urban Indigenous education. Race, Ethnicity and Education, 18(2), 251-276. 
James, C. E. (2011). Multicultural education in a color-blind society. In C. A. Grant \& A. Portera (Eds.), Intercultural and multicultural education: Enhancing global interconnectedness (Vol. 39, pp. 191-210). Abingdon, UK: Routledge.

Johnson, L., \& Joshee, R. (2007). Multicultural education policies in Canada and the United States. Vancouver, BC: UBC Press.

Kirkness, V., \& Barnhardt, R. (1991). First Nations and higher education: The four R's - Respect, relevance, reciprocity, responsibility. Journal of American Indian Education, $30(3), 1-15$.

Lawrence, B., \& Dua, E. (2011). Decolonizing anti-racism. In A. Mathur, J. Dewar, \& M. DeGagné (Eds.), Cultivating Canada: Reconciliation through the lens of cultural diversity (pp. 233-263). Ottawa, ON: Aboriginal Healing Foundation.

Lea, V. (2010). Empowering preservice teachers, students, and families through critical multiculturalism: Interweaving social foundations of education and community action projects. In S. May \& C. E. Sleeter (Eds.), Critical multiculturalism: Theory and praxis (pp. 33-46). New York, NY: Routledge.

Martinez, A., \& Andreatta, M. M. (2015). "It's my body and my life": A dialogued collaborative autoethnography. Cultural Studies $\leftrightarrow$ Critical Methodologies, 15(3), 224232. doi:10.1177/1532708614562901

Mathur, A., Dewar, J., \& DeGagné, M. (Eds.). (2011). Cultivating Canada: Reconciliation through the lens of cultural diversity. Ottawa, ON: Aboriginal Healing Foundation.

Mawhinney, J. (1998). "Giving up the ghost": Disrupting the (re)production of white privilege in anti-racist pedagogy and organizational change (Master's thesis). Ontario Institute for Studies in Education of the University of Toronto, Toronto, ON. Available at http://www.collectionscanada.gc.ca/obj/s4/f2/dsk2/tape15/PQDD_ooo8/MQ33991.pdf

May, S. (1999). Critical multiculturalism. London, UK: Falmer.

May, S., \& Sleeter, C. E. (2010). Critical multiculturalism: Theory and praxis. New York, NY: Routledge.

McIntosh, P. (2003). White privilege: Unpacking the invisible knapsack. In S. Plous (Ed.), Understanding prejudice and discrimination (pp. 191-196). New York, NY: McGraw-Hill.

Nguyen, M. (2011). Closing the education gap: A case for Aboriginal early childhood education in Canada, a look at the Aboriginal headstart program. Canadian Journal of Education, 34(3), 229-248.

Orlowski, P. (2008). "That would certainly be spoiling them": Liberal discourses of social studies teachers and concerns about Aboriginal students. Canadian Journal of Native Education, 31(2), 110-129.

Phung, M. (2011). Are people of colour settlers too? In A. Mathur, J. Dewar, \& M. DeGagné (Eds.), Cultivating Canada: Reconciliation through the lens of cultural diversity (pp. 289-298). Ottawa, ON: Aboriginal Healing Foundation. 
Porter, J. (1965). The vertical mosaic: An analysis of social class and power in Canada. Toronto, ON: University of Toronto Press.

Preissle, J. (2007). Feminist research ethics. In S. N. Hesse-Biber (Ed.), Handbook of feminist research: Theory and praxis (pp. 515-525). Thousand Oaks, CA: SAGE Publications.

Sanford, K., Williams, L., Hopper, T., \& McGregor, C. (2012). Indigenous principles decolonizing teacher education: What we have learned. In Education, 18(2), 18-24. Retrieved from http://ineducation.ca/ineducation/article/view/61/547

Saul, J. R. (2009). A fair country: Telling truths about Canada. Toronto, ON: Penguin Canada.

Schmidt, C. (2010). Systemic discrimination as a barrier for immigrant teachers. Diaspora, Indigenous, and Minority Education, 4(4), 235-252. doi:10.1080/15595692. 2010.513246

Simpson, J. S., James, C. E., \& Mack, J. (2011). Multiculturalism, colonialism, and racialization: Conceptual starting points. Review of Education, Pedagogy, and Cultural Studies, 33(4), 285-305. doi:10.1080/10714413.2011.597637

Singh, M. (2005). Identity conversion, citizenship, and social studies. In Y. Nozaki, R. Openshaw, \& A. Luke (Eds.), Struggles over difference: Curriculum, texts, and pedagogy in the Asia-Pacific (pp. 163-181). Albany, NY: State University of New York Press.

Sleeter, C. E., \& Milner, H. R. (2011). Researching successful efforts in teacher education to diversify teachers. In A. F. Ball \& C. A. Tyson (Eds.), Studying diversity in teacher education (pp. 81-104). Lanham, MD: Rowman \& Littlefield Publishers.

Smith, L. T. (2012). Decolonizing methodologies: Research and Indigenous peoples (2nd ed.). New York, NY: Zed Books.

Statistics Canada.(2015). Population projections for Canada (2013 to 2063), provinces and territories (2013 to 2038). Retrieved from http://www.statcan.gc.ca/pub/91-520x/91-520-x2014001-eng.htm

St. Denis, V. (2011). Silencing Aboriginal curricular content and perspectives through multiculturalism: "There are other children here." Review of Education, Pedagogy, \& Cultural Studies, 33(4), 306-317. doi:10.1080/10714413.2011.597638

Strong-Wilson, T. (2007). Moving horizons: Exploring the role of stories in decolonizing

the literacy education of white teachers. International Education, 37, 114-131.

Teacher Education Office. (2016). UBC teacher education viewbook. Retrieved from http://teach.educ.ubc.ca/students/resources/

Teaching for Indigenous Education. (2015). About. Retrieved from http://www. indigenouseducation.educ.ubc.ca/about-2/

Thobani, S. (2007). Exalted subjects: Studies in the making of race and nation in Canada. Toronto, ON: University of Toronto Press.

Tuck, E., \& Yang, K. W. (2012). Decolonization is not a metaphor. Decolonization: Indigeneity, Education \& Society, 1(1), 1-40. 
Tupper, J. (2013). Disrupting ignorance and settler identities: The challenges of preparing beginning teachers for treaty education. In Education, 17(3), 38-55.

UBC. (2013). Revised B.Ed. program evaluation data. Internal document.

UBC. (2015). Musqueam and UBC. Aboriginal portal. Retrieved from http:// aboriginal.ubc.ca/community-youth/musqueam-and-ubc/

Walsh, S. C., Brigham, S. M., \& Wang, Y. (2011). Internationally educated female teachers in the neoliberal context: Their labour market and teacher certification experiences in Canada. Teaching and Teacher Education, 27(3), 657-665. doi:10.1016/j. tate.2010.11.004

Williams, A. M. (2007). Listen to me, learn with me: International migration and knowledge transfer. British Journal of Industrial Relations, 45(2), 361-382.

Wright, H. K., Singh, M., \& Race, R. (2012). Precarious international multicultural education: Hegemony, dissent and rising alternatives. Rotterdam, The Netherlands: Sense Publishers.

Wyatt, J., Gale, K., Gannon, S., Davies, B., Denzin, N., \& St. Pierre, E. A. (2014). Deleuze and collaborative writing: Responding to/with "JKSB." Cultural Studies $\leftrightarrow$ Critical Methodologies, 14, 407-416.

$\mathrm{Yu}, \mathrm{H}$. (2011). Nurturing dialogues between first nations, urban Aboriginal, and immigrant communities in Vancouver. In A. Mathur, J. Dewar, \& M. DeGagné (Eds.), Cultivating Canada: Reconciliation through the lens of cultural diversity (pp. 299-311). Ottawa, ON: Aboriginal Healing Foundation.

\section{Contact Information}

Lilach Marom

Department of Educational Studies

University of British Columbia

Lilachmarom73@gmail.com

Lilach Marom has recently defended her dissertation, titled: "From Experienced Teachers to Newcomers to the Profession: The Capital Conversion of Internationally Educated Teachers in Canada." Her research is focused on questions of diversity in teacher education. She is a sessional instructor at the University of British Columbia and Simon Fraser University. 